FILOZOFIA

Roč. 76, 2021, č. 6

DOI: https://doi.org/10.31577/filozofia.2021.76.6.6

\title{
HOW “AMOR FATI" BECAME NIETZSCHE'S FORMULA FOR LEARNING TO LOVE NECESSITY AND HUMAN THRIVING $^{1}$
}

SVEN GELLENS, Ghent University, Department of Literary Studies, German Department, Ghent, Belgium

GELLENS, S.: How “Amor Fati” Became Nietzsche's Formula for Learning to Love Necessity and Human Thriving FILOZOFIA, 76, 2021, No 6, pp. 465 - 479

\begin{abstract}
This article addresses the ongoing debate on the meaning and scope of Nietzsche's formula for human greatness: amor fati. Identifying and exploring the constituents of amor fati, the article reconstructs the intellectual genesis of the philosophical concept in Nietzsche's writings and substantiates, through textual, chronological, and conceptual analysis, the pivotal meaning of these constituents (fate, love, and the judging activity of the body). This article provides insight into how amor fati functions as a transformative mindset, denoting a learning process between individuals and the world they inhabit, thereby allowing individuals to foster the highest form of interaction between their inner and outer environment.
\end{abstract}

Keywords: Amor fati - Judgment - Love - Science - Fate - Learning

\section{Introduction}

The traditional understanding of amor fati is highly problematic, as Tom Stern (2013, 157 - 158) claims, because Nietzsche scholars often select relevant passages from the Gay Science and explain these by other concepts than its own, most prominently the "eternal recurrence". This is not without problem and "[t]his would be unobjectionable if his views about some of the key notions associated with amor fati (in The Gay Science) were not subject to change in the coming years. As it happens, they were". In this article, I will offer an answer to this comment on the status quaestionis by providing a chronological and conceptual analysis of amor fati.

This approach aims to demonstrate that amor fati is a Nietzschean concept in its own right and aims to refocus the current status quaestionis in which scholars consider

\footnotetext{
${ }^{1}$ I would like to thank Benjamin Biebuyck and the anonymous reviewers of Filozofia for their valuable feedback on an earlier version of this article.
} 
amor fati a secondary concept subtended by the eternal recurrence, as Clark (1991) claims - also see Han-Pile (2011) for the most encompassing overview and Hatab $(2019,346)$ as its most recent proponent - or a flawed "fictional standpoint" as is proposed by Siemens (2009). Rather, amor fati is the culmination of an intellectual development between the years 1878, the year the first volume of Menschliches, Allzumenschliches was published and 1882, the year Die Fröhliche Wissenschaft appeared, wherein previously separated accounts will be synthesized in one single concept:

(1) the impact of pre-rational judging activity on the human organism throughout history,

(2) science, as a disciplined form of judging,

(3) love, as a force of affirmation and

(4) fate, as a denomination of embodied necessity.

In what follows, I will limit the discussion of these topics to amor fati in order to substantiate that the scope of amor fati in Nietzsche's philosophy goes beyond, as Clark (1991, 282) describes it, "[n]ot wanting anything different in the past". I will attempt to show that amor fati is a prospective learning principle that allows individuals to become who they are, thus explaining in greater detail why it is the "formula for human greatness" (EH, Clever, 10) and how it can be a functional principle to strengthen our lives.

\section{Judgments}

If we want to understand amor fati, we must first get a more detailed understanding on why the judging activity of humans is of any concern to their development and overall health, or as Stern $(2013,154)$ phrases it: "No doubt any attempt to understand the amor fati of The Gay Science must grapple with its insistence on error". Although Nietzsche accounts for this in the Gay Science, his analysis on this topic builds further on the one started in Menschliches, Allzumenschliches and Morgenröthe, which is overlooked in contemporary comments on amor fati.

\section{The activity of judging in Human, All Too Human and Daybreak}

The senses are formed to perceive in the way their design allows for. In a world where everything has become (MA 2), this points to an evolutionary process, which Nietzsche already hypothesized in aphorism 18 of the first part of Menschliches, Allzumenschliches. Here he analyzes the metaphysical belief in 'substance' as an offshoot of an inherited organic judgment. The aphorism provides a possible evolutionary 
explanation, waiting to be proved, for how such tendency of the perceptual process came to be.

One day it will be shown how gradually, in the lower organisms, this tendency comes into being: how the purblind mole's eyes of these organizations at first never see anything but the same thing; how then, when the various pleasurable and unpleasurable stimuli become more noticeable, various different substances are gradually distinguished, but each of them with one attribute, that is to say a single relationship with such an organism (MA 18).

Nietzsche's hypothesis is that perception is structured at its foundational level by experiences of pleasure and unpleasure (Lust und Unlust). ${ }^{2}$ For some reason, which he does not disclose, living organisms started to associate pleasure and displeasure with stimuli. A possible explanation for this association can be found in Riccardi's (2013) excellent article Nietzsche's Sensualism, where it is demonstrated that according to Nietzsche living beings experience quantitative differences in stimuli as qualitative. This pain-pleasure association transformed the world of perception from an undivided whole - "It may even be that the original belief of everything organic was from the very beginning that all the rest of the world is one and unmoving" (MA 18) - into a relationship with what presents itself, albeit structured through one attribute - "In our primary condition, all that interests us organic beings in any thing is its relationship to us in respect of pleasure and pain" (MA 18). These sensations, constituting the experience of a substance, leads to a new experience: a judgment.

The first stage of the logical is the judgement: and the essence of the judgement consists, according to the best logicians, in belief. At the bottom of all belief there lies the sensation of the pleasurable or painful in respect to the subject experiencing the sensation. A new, third sensation as a product of two preceding single sensations is the judgement in its lowest form (MA 18).

Nietzsche's transitive chain of reasoning supports him in drawing a three-fold general conclusion:

(1) if judgments are based on organic perceptual tendencies inherited from lower organisms, then metaphysics, although claiming to go beyond material elements,

\footnotetext{
${ }^{2}$ The English translation interchanges unpleasure, painful and pain for Nietzsche's usage of Unlust", schmerzhaft and Schmerz. Since Nietzsche uses the latter terms, in aphorism MA 18, in pairing with angenehm and Lust, we have opted, in the spirit of conceptual clarity, to consistently use 'pleasure' and 'unpleasure' as translations for Lust and Unlust.
} 
actually perpetuates organic perceptual tendencies that have more to do with survival than truth. In other words, metaphysics is a continuation of interests arisen out of the sensory domain.

(2) if judgments are based on organic perceptual tendencies inherited from lower organisms, then logic itself is still riddled with concepts that were evolutionary engrained perceptual structures, e. g. substances and freedom of will.

(3) belief can be understood as a sensuous presupposition that is rooted in an originary pain or pleasure sensation and can be applied to both sensory and conscious processes.

Thus: belief in freedom of will is a primary error committed by everything organic, as old as the impulse to the logical itself; belief in unconditioned substances and in identical things is likewise a primary, ancient error committed by everything organic. Insofar, however, as all metaphysics has had principally to do with substance and freedom of will, one may designate it the science that treats of the fundamental errors of mankind - but does so as though they were fundamental truths (MA 18).

Humans are historical beings that consist out of the accumulated judgments of lower life forms, judgments that are described in aphorisms MA $16 \& 18$ as "errors" and "fantasies". This organically rooted activity of judging is impossible to eradicate from human existence, not even by withholding or refraining from judging activities.

If only it were possible to live without evaluating, without having aversions and partialities! - for all aversion is dependent on an evaluation, likewise all partiality. A drive to something or away from something divorced from a feeling one is desiring the beneficial or avoiding the harmful, a drive without some kind of knowing evaluation of the worth of its objective, does not exist in man. We are from the very beginning illogical and thus unjust beings and can recognize this: this is one of the greatest and most irresolvable discords of existence (MA 32).

The discord of existence, as Nietzsche calls it, is the tension between inescapably being shaped by unconscious judging and being aware of the erroneous nature of judging. Menschliches, Allzumenschliches aims at providing an answer to this experience of disharmony of human existence. By addressing and correcting the process of judging in a specific way Nietzsche argues for a transformation of humanity that in time - will involve a redemption of its 'illogical' organic determination. This transformation is towards "a knowing humankind" (MA 107), supplanting the organically 
rooted habit of erroneous judging with an accumulation of knowledge by science. Gradually, in "thousands of years' time," this will result in a new habit (Gewohnheit) of comprehending (die des Begreifens):

Even if the inherited habit of erroneous evaluation, loving, hating does continue to rule in us, under the influence of increasing knowledge it will grow weaker: a new habit, that of comprehending, not-loving, not-hating, surveying is gradually implanting itself in us (MA 107).

Establishing a preponderance of the habit of comprehending by the spirit of science (also see MA 224), the human organism can become more healthy. Interestingly, as we can read in aphorism 285, this is an indispensable correction (nothwendigen Correcturen) to humankind. If humans want to stop yielding to their inveterate erroneous habit of judging or valuating, they have to enhance the contemplative (beschauliche) element in their nature. The habit of comprehending can ultimately be understood as a general useful virtue (allgemein nützliche Tugend) that will bring humankind to greater heights. Science, as our most systematic approach to knowledge, is to be consciously employed to correct, strengthen, and enrich human nature, which is entangled with incorrect valuations from lower organic lifeforms. The scope of this transformative approach in the "spirit of optimistic rationalism", as Moore $(2004,60)$ calls it, to the judging activity of individuals, and eventually human nature, becomes even more transparent in love, "Liebe" in German.

\section{Love and science}

Love, properly employed through scientific reasoning, is able to temper man's habit of valuating. In MA 621, Nietzsche describes the method (Verfahren) of utilizing love as an artifice-Liebe als Kunstgriff as the aphorism is entitled - and more specifically an artifice of reason. When one wants to obtain knowledge about a new stimulus, which could be "a person, an event, a book," one can use love as a pretext to lure out the dynamic reality of that which is presenting itself. Although in a quick reading of the aphorism it might seem as if love and reason were being opposed to one another, in the sense that reason acts against love in order to curb its over-heated actions. Nietzsche argues that love is 'cognitively' important too, for it allows one to "penetrate $[\ldots]$ to the heart of the new thing." With this conception of love, he goes well beyond the transcendental epistemological claim that while perceiving, the perceiver does not comment on the ontological status of the object perceived, since it temporarily invites the perceiver to approach this object more intimately than reason would ever do: 
He who really wants to get to know something new (be it a person, an event, a book) does well to entertain it with all possible love and to avert his eyes quickly from everything in it he finds inimical, repellent, false, indeed to banish it from mind [...] For with this procedure one penetrates to the heart of the new thing, to the point that actually moves it: and precisely this is what is meant by getting to know it. If one has got this far, reason can afterwards make its reservations; that over-estimation, that temporary suspension of the critical pendulum, was only an artifice for luring forth the soul of a thing (MA 621).

The procedure Nietzsche speaks of should not be interpreted as an essentialist move, an attempt to grasp the essence of the object perceived, because the locus of movement of the object - "the heart" or "the soul" - is itself a moving point, a part in a dynamic process of eliciting information, phrased in the aphorism as "luring" (herauszulocken). The use of love in order to know and understand something new, is, therefore, a heuristic "temporary suspension of the critical pendulum." The specific image of a "pendulum" expresses the necessity to return to the critical attitude of reason, making a claim for esotericism- as Lampert $(1995,48)$ wrongly assumed implausible.

This procedure is explained in greater detail in Morgenröthe, where Nietzsche describes that love itself needs boundaries. He begins aphorism 479, called Love and truthfulness, by forewarning the consequences of the manipulative impact of love with regard to truthfulness (Wahrhaftigkeit). All too often, he says, the thinker renounces his reason in favor of being seduced "for the sake of love." ${ }^{3}$ Nonetheless, Nietzsche adds that truth seduces us as well. Truth is dynamic. As a knower we can overpower the object leading to subjectivity, so that one becomes a transgressor (Verbrecher) against truth. This implies that in the process of knowing, there appears to exist a point when a perceiver can no longer speak truthfully about an object; when this point of transgression towards truth occurs, a receiver (Hehler) becomes necessary. A human's ability to transgress against truthfulness is further explained in M 532, entitled Love makes the same. Love all otherness: the distinction between lovers disappears; they merge into one another. The brackets in the title of the aphorism suggest, however, that love does not make everything equal, but feigns "a sameness which in reality does not exist," giving the impression of being equal by deceit.

Love wants to spare the person to whom it dedicates itself every feeling of being other, and consequently it is full of dissimulation and pretense of

\footnotetext{
${ }^{3}$ For more on seducing in love see M 517 and M 539 and on the unmeasured utilization of love see AC 23 and AC 30.
} 
similarity, it is constantly deceiving and feigning a sameness which in reality does not exist (M 532).

From this overview, we agree with Chouraqui $(2015,267,278$ - 279) that Nietzsche-research on love focusses on the traditional meaning of love, which has an object $^{4}$, while another meaning of love, as "a pathos [that] precedes the encounter with its object", receives little attention. As the aphorisms above show Nietzsche uses love as an affective state independent of an object - an epoché, as Chouraqui (2015, 277) calls it - making it a constitutive force that belongs to the deepest regions of human organic nature. Love, as we can read in MA 603, "desires" and "recognizes no power, nothing that separates, contrasts, ranks above and below". In aphorism 262 of Morgenröthe love is even coupled with power as "love to power" (Liebe zur Macht) and characterized as a "demon" for humans: a more fundamental organic power than desire (Begierde) or necessity (Nothdurft) with regard to satisfaction. Interestingly, Nietzsche writes that it is not about fulfilling a want with an object of satisfaction. When everything is taken from people and only their love to power is satisfied "they are almost happy - as happy as men and demons can be". Brusotti $(1997,67 \mathrm{f} 87,70)$ describes love to power as one of many variations Nietzsche uses to denote the feeling of power (Gefühl der Macht) and calls it the "Grundtrieb", a primary drive or force that was a "cultural fact" in ancient Greek society. Love is therefore not only a descriptive state of a loving subject or an interpersonal emotional state, but, first and foremost, as Chouraqui $(2015,270)$ writes, "an ontological principle $[\ldots]$ it is love that precedes both its subject and its object, and constitutes them". Nietzsche writes about many forms of love, such as love between the sexes (FW 363), sexual love (FW 14), love for artistry (FW 80) or Christian charitable love (JGB 201). However challenging they may be, these typologies of love fall outside the scope of this article, just as much as, possible (genealogical) links between love and power in the middle works and the question how they relate to each other in the later works. Nevertheless, we can conclude that love, in the middle works, is acknowledged for its affective comprehension that seemingly does not allow for a differentiation between a knower and a known, but even then, it 'feigns' this sameness. Love, as we can also read in aphorism 57 of Vermischte Meinungen und Sprüche, contributes to "understanding" and "rejoicing". It can bridge "opposites" (Gegensätze) through joy, but should not annul the manifested plurality (Vielheit) in events (even within

\footnotetext{
${ }^{4}$ Also see Sterns $(2013,148)$ dismissal of Han-Pile's account of amor fati, based on the ground that Nietzsche's use of love goes beyond either eros or agape, or the unjustified claim that Nietzsche writes so little on love (Han-Pile 2011, 224 - 225).
} 
individuals) in the form of selflove (Selbstliebe). Now that we have elaborated on judging and love in MA and M, let us turn to our final track for understanding amor fati: fate.

\begin{abstract}
Amor fati
Josefine Nauckhoff correctly translates the concept "amor fati" as "love of (one's) fate", adding "(one's)" in parentheses and thus demonstrating the synonymy of the individual's fate and fate in general. In the context of fate, one crucial aphorism requires a thorough analysis. In the second part of Menschliches, Allzumenschliches, aphorism 61 of Der Wanderer und sein Schatten eloquently describes the individual as "a piece of fate." It provides Turkish fatalism, ${ }^{5}$ also the title of the aphorism, as an example of how fate is mostly misunderstood. Turkish fatalism sets man against fate as two separate things, while, Nietzsche clearly states, man and fate concern an identical relation. This becomes apparent in the analysis that when an individual feels joy or fear towards what happens to him, this is not an attitude towards his fate, but is a manifestation of his fate.

In reality every man is himself a piece of fate; when he thinks to resist fate in the way suggested, it is precisely fate that is here fulfilling itself; the struggle is imaginary, but so is the proposed resignation to fate; all these imaginings are enclosed within fate... The follies of mankind are just as much a piece of fate as are its acts of intelligence: that fear in face of a belief in fate is also fate. You yourself, poor fearful man, are the implacable moira enthroned even above the gods that governs all that happens; you are the blessing or the curse and in any event the fetters in which the strongest lies captive; in you the whole future of the world of man is predetermined: it is of no use for you to shudder when you look upon yourself (WS 61).
\end{abstract}

The ending of the aphorism is remarkable. How can an individual's fate be understood as a predetermination of "the whole future of the world of man" (in dir ist alle Zukunft der Menschen-Welt vorherbestimmt)? ? $^{6}$ Aphorism 41 of MA might provide an answer. Here, Nietzsche makes the point that humans and humankind do not have an unalterable character, and simply do not possess a life-span long enough to omit all developments that have engrained themselves in the body over the course of history.

\footnotetext{
${ }^{5}$ It is remarkable that the English translation opts for "Mohammedan" while Nietzsche writes about the fatalism of the Turks (Türkenfatalismus). In my translation, I follow the German original. ${ }^{6}$ Also see in this context "Myself, as a piece of fate" [Ich, als fatum] Nachlass 1882/84, 16 [83], KSA 10.526 and Nachlass 1882/84, 16 [64], KSA 10.522.
} 
The unalterable character. - That the character is unalterable is not in the strict sense true; this favourite proposition means rather no more than that, during the brief lifetime of a man, the effective motives are unable to scratch deeply enough to erase the imprinted script of many millennia. If one imagines a man of eighty-thousand years, however, one would have in him a character totally alterable: so that an abundance of different individuals would evolve out of him one after the other. The brevity of human life misleads us to many erroneous assertions regarding the qualities of man (MA 41).

Fate and a predetermination of the future of individuals, explained in WS 61, poses the question of determinism, as phrased by Brusotti (1997, 158 - 159): "When the drives have decided everything beforehand, is then even a correctly designed ideal not superfluous, even in the most favorable case, when it is actually achieved?" While Brusotti $(1997,158$ - 160) claims that in the middle works Nietzsche does not really answer this question, I think that an answer can be found. The fates of individuals appear aligned with their historical development. This alignment is not incongruous, because it refers to the scope of possible transformations that individuals are capable of in their lifetime. In characterizing an individual as an amalgam encompassing the entire pre-history of organic life, Nietzsche binds this evolutionary development with the concept of "fate". ${ }^{7}$ Certain organic developments (e.g., our perception of individuals and substances, our inner organization through instincts, feelings, et cetera) cannot be elided from one's constitution: these ancient sedimentations guide and structure the individual's judgments and actions. The variety of behavioral possibilities to be actualized in an individual's lifetime are as such predetermined and provide a horizon for the individuals themselves as a piece of (future) humankind. This makes a local fatalism, such as Clark (1991) advocates, implausible. ${ }^{8}$ Nietzsche's understanding of fate is not localized, it concerns the complete acceptance of an individual's inner organization, which is always interactively embedded in its external environment. This can be well illustrated with a reference to aphorism 231 of Jenseits von Gut und Böse where he elaborates on the tension between ourselves as transformative beings, i.e. "[l] earning transforms us", and as fated beings, i.e. "there is clearly something that will not learn". What will not learn, lies at our "foundation" and is called a "granite of spiritual fatum": it is made of "predetermined decisions and answers to selected, predetermined questions." Nietzsche also describes it as "an immutable 'that is me' [that] speaks up". Humans are historically shaped organisms that interact with the

\footnotetext{
${ }^{7}$ Also see Bornedal (2010, 468).

${ }^{8} \mathrm{We}$ will provide further evidence of this in our chronological analysis of amor fati further in the text.
} 
world through evaluative tendencies. These evaluations are so deeply embodied that they cannot be omitted from the body in one lifespan. This fatum of organic existence is to be studied, explored, fully accepted and loved as something necessary to oneself. Returning to our original reading of WS 61, our analysis above can help clarify Nietzsche's identification between "the whole future of the world of man" and the individual in his conclusive remark of the aphorism: "it is of no use for you to shudder when you look upon yourself" (WS 61). Individuals can become prospective to human greatness when they accept this fatum and explore the configurations of their body and the judgments that correspond to these. This acceptance is what Nietzsche calls love of (one's) fate, amor fati:

My formula for human greatness is amor fati: that you do not want anything to be different, not forwards, not backwards, not for all eternity. Not just to tolerate necessity, still less to conceal it - all idealism is hypocrisy towards necessity - , but to love it... (EH, Clever, 10).

As such, this reading proposes a solution to the "enormous difficulties" (Siemens 2015,83 ) in Nietzsche's use of the term of necessity. In his excellent article, Siemens claims Nietzsche achieves a singular concept of facticity that encompasses necessity and possibility by "collapsing" both meanings into actuality. It remains unclear whether "facticity is meant to displace the concept of necessity as an alternative to the language of necessity, or to reinterpret it as a minimal concept of necessity" (Siemens 2015, 100 - 101). My analysis shows that what Nietzsche calls actuality is not a conceptual "displacement" of necessity, but is actuality itself. In other words, actuality is infused through the meaning of necessity. This prompts us to realize the full importance of the psychological question of Nietzsche's philosophical oeuvre, which is concerned with the impact of ideas, i.e., the eternal return or amor fati as cultural determinants on the body, and is itself an experimental actualized practice in order to find an answer or "a map sketching out the contours of our task", as Maudemarie Clark $(2018,228)$ puts it.

To substantiate this reading further, I will provide a concise chronological analysis of the concept of amor fati. A pivotal Nietzschean concept, it is remarkable that "amor fati" only occurs in ten textual instances: four published, five in the Nachlass, and one in a letter to Overbeck. ${ }^{9}$ Nevertheless, they give evidence to a gradual refinement of the idea, nuancing Stern's $(2013,158)$ observation of the difference between amor fati in its first published form in 1882 and its portrayal in the later works. From the

\footnotetext{
${ }^{9}$ The reference to amor fati in the letter to Overbeck does not add to the status quaestionis, hence, I will not go into it.
} 
first formulation in an unpublished fragment (Nachlass 1880/82, 15 [20], KSA 9.643), to the last occurrence in EH WA 4, amor fati systematically consists of three main aspects: necessity (Nothwendigkeit), or what is necessary in things, loving (lieben) this necessity, and learning how to accomplish this.

In the earliest descriptions noted down during the fall of 1881 (Nachlass 1880/82, 15 [20], KSA 9.643 and Nachlass 1880/82, 16 [22], KSA 9.664), amor fati is an elaboration on accepting both fortunate (alles Gute and Gratien) and unfortunate (schreckliche Herkunft, Furien) events as equally valuable aspects of life. At the start of the fourth book of Die Fröhliche Wissenschaft, in aphorism 276, Nietzsche nuances this love for the necessity in things as a learning process - as learning to see what is beautiful in necessity. In this process, individuals try to obtain more knowledge about the world that surrounds them by means of love to go beyond the mere epistemic appearance of the thing and to grasp what is necessary in it.

This understanding of amor fati is reinforced by a note Nietzsche wrote in the summer of 1888 (Nachlass 1887/89, 16 [32], KSA 13.492). In this annotation, the terms "dionysian" and "Dionysian yes-saying" enter the semantic field of amor fati. In this stage of his writing, "Dionysian" denotes the intellection that one's fate encompasses both fortunate and unfortunate aspects and that affirmation is the highest way of interaction with the world a philosopher can attain (through standing in a Dionysian relation to being, which is synonymous with amor fati).

Such an experimental philosophy, in the way that I live her, anticipates experimentally even the possibilities of a fundamental nihilism: this does not mean that she would halt at a no, at a negation, at a will to no. She would rather up to the opposite point - to the Dionysian affirmation of the world as she is, without deduction, exception and selection - she wants the eternal cycle -, the same things, the same logic and illogicality of nodes. The highest condition a philosopher can obtain: to take a Dionysian stance towards existence -: my formula for that is amor fati... (1888 VIII 16 [32], 13.492, my translation).

Explicitly placing amor fati within the context of "an experimental philosophy," shows it concerns a transformative interaction with the world. This is elaborated in another amor fati fragment, written early in the year of 1889 (Nachlass 1887/89, 25 [7], KSA 13.641), where he talks about life as an experiment of knowledge - to reiterate a turn of phrase of FW 324. Nietzsche describes key historical persons, events and movements ("Bismarck", "Kant", "1848", "Christianity", ...) as necessary constituents of his own life-path. Even what he calls the "great crimes of the Germans against culture" is interpreted as a necessary step towards a "higher economy" of 
culture. All historical developments are inescapable elements of a learning process: "a vivisection of life." The wording of a "higher economy" in the context of amor fati returns in published form in the epilogue of Nietzsche Contra Wagner where Nietzsche, for the first time, claims he has incorporated amor fati as "his innermost nature", referring again to his tenet that an individual is an expression of fate.

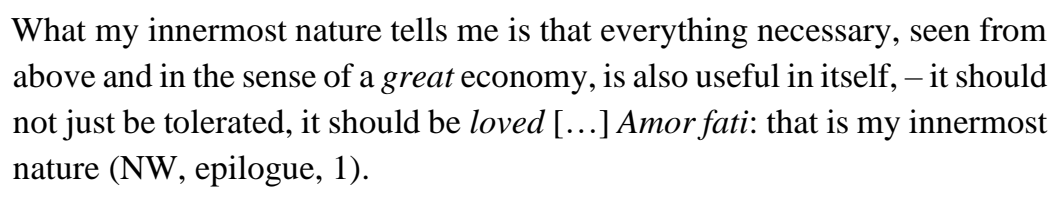

In describing amor fati as his innermost nature, Nietzsche claims to having successfully completed the learning process of applying love as a means to gain more knowledge about the world and himself, for, as he states in FW 334 One must learn to love.

This analysis of amor fati shows it is a bios: a philosophical or psychological concept that realizes itself through practice, as Elgat $(2016,177,183)$ convincingly argues. ${ }^{10}$ Therefore, I disagree with Siemens $(2009,203)$ who understands the affirmative position of amor fati to be an unachievable "fictional standpoint" and determines Nietzsche's self-portrayal in EH as "a hyper-identity of an I inflated to world-historical, not to say cosmic proportions" (Siemens 2009, 183). Amor fati is not about inflating oneself to cosmic proportions as a means to transcend all oppositions, rather, it is about breeding oneself to become who you are. It is concerned with self-experimentation and therefore links up perfectly with Nietzsche's appeal to consider life as "an experiment for the knowledge-seeker" (FW 324).

\section{Conclusion}

In this article, I have shown that amor fati is the result of an intellectual process of refinement, in which four, originally separate accounts are theorized into one consistent conceptual whole: fate concerns the inescapable inner (instinctual) organization of the individual configuring its judgments, and love and (scientific) knowledge can be deliberatively applied to know more about oneself and the world. Specifically, Nietzsche makes clear that love can work as a centripetal force when employed as a deliberate attempt to get to know an object, and that science or scientific knowledge enable individuals to understand the structure of their judging activity. Amor fati synthesizes fate and love into a coherent formula that addresses individual development.

${ }^{10}$ Compare this to Stern $(2019,372)$ who determines that "it is doubtful that affirmation, in any way that Nietzsche understands it, can function for us as a significant ethical ideal". 
As such, I have substantiated in detail what Thiele $(1991,88)$ already noticed: "for Nietzsche love and judgment were interdependent faculties. An analysis of their dynamics goes to the core of Nietzsche's understanding of the human condition." As a transformative principle, amor fati not only seems to impact an individual's life but also entails a re-evaluation of human social life. The fifth book of Götzen-Dämmerung makes clear that a lifestyle of amor fati replaces erroneous moralities that want to reduce the world, characterized as an "enchanting abundance of types, a lavish profusion of forms in change and at play", to one type of human with the affirmative mindset that expresses the belief that every "individual is a piece of fate, from the front and from the back; an individual is one more law, one more necessity imposed on everything that is coming and going to be" (GD Widernatur 6). This immoralist position, as Nietzsche calls it in the aphorism, which "opened our hearts to all types of understanding, comprehension, approval", might be further explored for its prospective power of socialization by the concept of Einverleibung, as put forward by Siemens $(2016172,176)$ who describes it as a process of interiorization of values of the community and as a learning process for the appearance of the sovereign individual. This might be the subject of follow-up research. This article lays the groundwork for understanding amor fati as a concept in its own right and, as such, can provide a solid basis for further exploration of new perspectives on the concept and other important topics in Nietzsche's philosophy.

I will conclude this article by illustrating this briefly with the help of the concept of the historical sense (der historische Sinn). This concept clarifies the experiential dimension of amor fati as a learning process in greater detail. Amor fati denotes an experimental exploration of one's own physical and genealogical constitution - "To say to an individual: 'change yourself' means demanding that everything change, even retroactively" (GD Wiedernatur 6) - which seems to demand an almost athletic capability to learn from ones actions. This existential pervasiveness of the transformative learning process of amor fati defines it as the formula for human greatness and denotes why not many, but only few can attain this lifestyle. Why this is the case, may be explained by looking at the development of one's "historical sense" and the necessary mental and physical endurance to incorporate the knowledge this new sense "This is the beginning of something completely new and strange in history" - opens up to the individual. In aphorism $337^{11}$ of Die fröhliche Wissenschaft Nietzsche describes the historical sense as generating a feeling (Gefühl) that enables "to feel the history of man altogether as his own history". This experience is an accumulation of (historical) events and emotional states into a "monstrous sum", huddled "into one

\footnotetext{
${ }^{11}$ The Nietzsche-Wörterbuch $(2004,43)$ indicates that in FW 337 amor fati is seen as the motor of a new aristocracy ('neuer Adel').
} 
feeling". The historical sense, a recently acquired sixth sense (JGB 224), can hence clarify why amor fati functions as a learning process. It seems that developing one's historical sense functions as an enabler for the scope of amor fati: how much 'truth', to get back to a turn of phrase of FW 110, how much monstrosities and benefits of humankind's development can we incorporate into ourselves. Insofar as the historical sense can prime the transformative power of amor fati (and vice versa), it may well disable the dynamics of ressentiment (EH Weise 6) - but this would require further research. What is clear is that amor fati functions as a principle of personal development and human thriving, which expresses the highest form of interaction with the world, without making normative claims about the existence of an external reality that functions as the measure of truthfulness. Rather, it helps individuals to refine their own judgments and thus allows them to manifest behavior as a unique expression of themselves. Following the learning process of amor fati, humans can truly transform themselves into distinctive beings, whose lives reveal a unique perspective on life.

\section{Bibliography}

BORNEDAL, P. (2010): The Surface and The Abyss, Nietzsche as Philosopher of Mind and Knowledge. Monographien und Texte zur Nietzsche-Forschung 57, Berlin - New York.

BRUSOTTI, M. (1997): Die Leidenschaft der Erkenntnis - Philosophie und ästhetische Lebensgestaltung bei Nietzsche von Morgenröthe bis Also sprach Zarathustra. Berlin/New York.

CHOURAQUI, F. (2015): Nietzsche's Science of Love. Nietzsche-Studien 44 (1), 267 - 290.

CLARK, M. (2018): Nietzsche: Old and New Questions. The Journal of Nietzsche Studies, 49 (2), $228-233$.

CLARK, M. (1991): Nietzsche on Truth and Philosophy. Cambridge: Cambridge University Press, 282.

ELGAT, G. (2016): 'Amor fati' as practice: how to love fate. The Southern Journal of Philosophy, $54(2), 174-188$

HAN-PILE, B. (2011): Nietzsche and amor fati. European Journal of Philosophy, 224.

HATAB, L. (2019): The Will to Power. In: Stern, T. (ed.): The New Cambridge Companion to Nietzsche. Cambridge: Cambridge University Press, $329-350$.

LAMPERT, L. (1995): Nietzsche, The History of Philosophy, and Esotericism. The Journal of Nietzsche Studies, No. 9/10, $36-49$.

MOORE, G. (2004): Nietzsche, Biology and Metaphor. Cambridge: Cambridge University Press.

NIETZSCHE, F. (1999): Kritische Studienausgabe in fünfzehn Bänden (KSA). Ed.: G. Colli - M. Montinari. München: De Gruyter.

NIETZSCHE, F. (2001): The Gay Science. With a Prelude in German Rhymes and an Appendix of Songs. Ed.: B. Williams. Trans.: J. Nauckhoff, A. Del Caro. Cambridge: Cambridge University Press.

NIETZSCHE, F. (2002): Beyond Good and Evil. Prelude to a Philosophy of the Future. Eds.: R.-P. Horstmann - J. Norman. Trans. J. Norman. Cambridge: Cambridge University Press.

NIETZSCHE, F. (2005): The Anti-Christ, Ecce Homo, Twilight of the Idols, and Other Writings. Eds.: A. Ridley - J. Norman. Trans. J. Norman. Cambridge: Cambridge University Press. 
NIETZSCHE, F. (2003): Writings from the Late Notebooks. Ed.: R. Bittner. Trans. K. Sturge. Cambridge: Cambridge University Press.

NIETZSCHE, F. (2008): Human, All Too Human. Trans. R. J. Hollingdale. Cambridge: Cambridge University Press.

NIETZSCHE, F. (2009): Daybreak. Thoughts on the Prejudices of Morality. Ed.: M. Clark and B. Leiter. Trans. R. J. Hollingdale. Cambridge: Cambridge University Press.

RICCARDI, M. (2013): Nietzsche's Sensualism, European Journal of Philosophy, 21 (2), 219 - 257.

SIEMENS, H. (2016): Nietzsches Sozio-Physiologie des Selbst und das Problem der Souveräntität. In: Heit, H. - Thorgeirsdottir, S. (eds.): Nietzsche: Denker der Kritik und der Transformation. Berlin - Boston: de Gruyter, 167 - 182.

SIEMENS, H. (2015): Nietzsche's Concept of "Necessity" and Its Relation to "Laws of Nature". In: Lemm, V. (ed.): Nietzsche and the Becoming of Life. New York: Fordham University Press, $82-102$.

SIEMENS, H. (2009): Umwertung Nietzsche's "war-praxis" and the problem of Yes-saying and No-saying. Ecce Homo, Nietzsche Studien. Vol. 38, 182 - 206.

STERN, T. (2013): VIII - Nietzsche, Amor Fati and The Gay Science. Proceedings of the Aristotelian Society, 113 (2_pt_2), 145 - 162.

THIELE, L. P. (1991): Love and judgement: Nietzsche's Dilemma. Nietzsche-Studien. Vol. 20 Berlin - New York: De Gruyter, 88 - 109.

TONGEREN, P. J. M. van, SCHANK, G., SIEMENS, H. (2004): Nietzsche-Wörterbuch. Vol. 1: Abbreviatur-einfach. Berlin: De Gruyter.

Sven Gellens

Ghent University

Department of Literary Studies

German Department

Blandijnberg 2

B-9000 Ghent

Belgium

e-mail: sven.gellens@ugent.be

ORCID ID: https://orcid.org/0000-0002-8663-2062 